\title{
Factors that Influence Secondary School 'Teachers' Acceptance of E-learning Technologies in Teaching in the Kingdom of Saudi Arabia
}

\section{Dr. Abdulrahman Mohammed Alzahrani}

University of Lincoln, School of Education, UK

\section{ABSTRACT:}

he researcher used the technology acceptance model
(TAM) to investigate the attitudes and factors, which
influence secondary school teachers' acceptance of e-learning technologies in teaching in the city of Mecca in Saudi Arabia. Using a questionnaire, data was collected from 38 secondary schools, and 509 valid usable responses obtained. The participants were chosen at random, and hence the sample is not discriminatory in terms of teachers' gender, subject specialisations, ages and others. The data was analysed by using SPSS 21.0 package and the Smart PLS 2.0 program, The findings indicate that the TAM can be used to explain the factors influencing teacher technology acceptance, in Saudi Arabian context.

\section{Introduction}

Although there are different definitions of e-learning within the academic literature, generally, it can be considered as the use of information and communication technologies (ICT) in a teaching environment. Hence, it would include using a computer, the Internet, software, whiteboards, electronic games, email and a virtual learning environment during the process of teaching and learning. In this research, a more specific educationalparadigm-oriented definition of e-learning will be used. According to this paradigm, e-learning is an improvement to traditional learning because it uses modern technologies, including the Internet, for learning and teaching.

Since the 1970s researchers have been attempting to identify the factors that influence the use and acceptance of technology (Legris et al., 2003). However, the techniques and technologies associated with e-learning can also be used as a component of what has become known as blended learning. In a blended learning situation, e-learning technologies in the classroom are combined with more traditional types of face-to- 
face instruction by teachers sharing knowledge with pupils in the school classroom. In secondary schools, this type of blended learning appears particularly advantageous because it allows students to meet the required attendance at the sessions, whilst they may benefit from sharing materials online and cooperating in virtual learning environments. In the context of Saudi Arabia, using e-learning techniques in this way has the additional advantage of allowing teachers of one gender to give instruction to pupils of another gender, but virtually, so that they are not physically in each other's presence.

According to many education researchers Bell et al. (2007, 64), for example, carried out research into the use of online support to enhance student mobility among nursing and economics degree students at the University of Salford, and found that " $84.7 \%$ of students agreed or strongly agreed that the collaborative activity (enabled by ICT technologies) was beneficial to their education", and "only 3\%... had expressed a negative attitude". The result of this and similar research shows clearly that using new technologies for learning produces a benefit for students during their studies.

Such research suggests e-learning projects should be of great benefit in improving teaching and learning in educational environments. Previous research, undertaken in many countries, has focused on various elements of e-learning, including students' experience of the use of e-learning. In Saudi Arabia, the adoption of new technologies in teaching and learning has occurred more slowly than in Western nations, although within higher education there have been a number of studies that have considered how to overcome the problems in order to increase the acceptance of e-learning by teachers in teaching and learning. Consequently, this research is the first research into the acceptance of e-learning technologies in secondary schools in Saudi Arabia.

The ability to achieving high quality learning outcomes by means of using new technologies is influenced by different elements in the teaching process. These include the teacher's 
personality, which will be influenced by their age, gender, level of education, specialisation and teaching experience. Other important factors include teachers' technical and pedagogic competencies, their ICT skills and extent to which they have benefitted from teachers' in-service training in the field of educational technology. All these factors led the researcher to ask the question, "What are the factors that influence secondary school teachers' acceptance of e-learning technology in teaching in Saudi Arabia?"

\section{Literature review: Learning and ICT in Secondary Schools in Saudi Arabia:}

In recent years, the telecommunications market in Saudi Arabia has grown exponentially. The market was liberalised in 2007, leading to lower prices and a more competitive industry, and since then, there has been significant growth in the use of the internet and mobile technology in the country (Lobo and ElalufCalderwood, 2012). In the year 2000, only 0.9 percent of the population used the internet, but this had grown to 66 percent by 2015 (Internet World Stats, 2015). The use of mobile technology has similarly increased: a recent report by the United Nations Conference on Trade and Development (UNCTAD) indicated that Saudi Arabia has the largest numbers of mobile phone users worldwide (Ahmed, 2013), and it is also the highest rated country in terms of the amount of time people spend on the internet on their mobile phones (Mari, 2013). The increasingly affordable internet connection and the ubiquitous use of technology in the country is both fuelled by and fuelling a shift towards a digital economy, and the government is investing large amounts of money in e-government, e-health, e-commerce, and the largest amount in e-education (Lobo and Elaluf-Calderwood, 2012).

However, despite the fact that there has been massive spending and governmental support in the implementation and use of ICT in secondary schools, research studies from this context indicate that ICT is not being used effectively in schools and there are a number of barriers preventing its successful 
implementation (Oyaid, 2009; Ageel, 2011; Almalki and Williams, 2012; Al-Harbi, 2014; Al-Mulhim, 2014: Albugarni and Ahmed, 2015). These reports and other anecdotal evidence reveal common problems across different educational contexts: there is a lack of a common, effective strategy to implement the use of ICT in secondary education, there is a lack of technical support for teachers using the technology, the traditional methods of teaching used in schools are not compatible with the methods associated with e-learning and teachers are not receiving training in how to implement new approaches, neither are teachers being given technological training in how to use the resources. Furthermore, it has been reported that many schools lack basic equipment and software, particularly in girls' schools where there is less investment in general, and there are worries that allowing students access to the internet will encourage interaction between genders (Mohamed et al., 2008). In addition, it has been reported that the internet connection in rural communities is still poor due to the large size of the country and its mountainous areas, and as a result, there are structural barriers to the implementation of e-learning in these communities (Almarwani, 2011; Al-Shehri, 2012).

Therefore, while in general there have been enormous improvements and investment in the ICT infrastructure of Saudi Arabian secondary schools in recent years, there are still many problems to be resolved and, as of yet, ICT is not being used to its full potential in this context.

\section{TAM in E-Learning:}

In recent years a number of researchers have turned their attention to whether the TAM can be used to study the adoption of e-learning; Sumak et al. (2011) conducted a meta-analysis of research into the adoption of e-learning and found that 86 per cent of the studies used the TAM to investigate the users' elearning adoption. In general, research seems to indicate that this model can be applied to the e-learning context, for example Sumak et al. (2011) concluded that the TAM was a suitable model for the study of the adoption of e-learning and Islam et al. (2014, 
172) studied the application of this model to the e-learning context and found that, philosophically, "there is no problem in applying TAM and its variants in e-learning adoption". However, these authors note that as TAM does not contain any specific variables which are related to e-learning, this model should be revisited and adapted for the e-learning context due to the fact that an educational system is different from a general IS in at least some respects. For example, whereas a general IS often offers users resources that are ready to use, an e-learning system may provide educators and learners with 'possibilities' that they have to apply to their own circumstances (Shee and Wang, 2008). Furthermore, a general IS usually elicits performance from individual users, while e-learning relies on the interaction between educator and learner, with both parties contributing to the success of the technological interaction (Shee and Wang, 2008). Moreover, a number of unique factors may contribute to the success or rejection of an e-learning system which may not apply to a general system, for example, educators' roles and teaching beliefs, learners' feelings of isolation, the availability and/or sharing of hardware, and so on (Pelgrum, 2001; Schoepp, 2005). As such, when using the TAM in an e-learning context, these differences and their effect on PU, PEOU, attitude, BI and actual usages should be investigated in order to provide valuable information for practitioners wishing to implement e-learning systems.

A number of studies have investigated how the TAM can be adapted to make it more applicable to the e-learning context. For example, the technical support teachers perceive is available to them has been shown to influence the adoption of e-learning. Ngai et al. (2007) and De Smet et al. (2012) both found that perceived access to technical support positively influenced both PU and PEOU in the adoption of a learning-management system at a university and a secondary school respectively. Furthermore, a teacher's self-efficacy of teaching with technology has been shown to have a strong influence on technology use. Gong et al. (2004) found that computer self-efficacy directly effects PEOU and intention to use e-learning systems, and Chen (2010) found 
the pre-service teachers' self-efficacy, mediated by their belief about the usefulness of technology to teaching and learning, had the strongest influences on technology use. Therefore, it would seem that an adapted TAM, which takes into account the unique features of technology for learning is a suitable model for studying the adoption of e-learning.

\section{The ELTAM design for this research:}

After carefully considering all the previous versions of the TAM chronologically the researcher selected the modified version of TAM, which was created by Davis in 1989, and developed the electronic learning technology acceptance model (ELTAM).

TAM model was chosen for two reasons. Firstly, a meta analysis by Sumak et al. (2011) indicated that TAM model was used by $86 \%$ of research studies in examining the adoption of elearning and concluded that the TAM was a suitable model for the study of acceptance of e-learning. Secondly, prior researchers used TAM model in Middle Eastern context. For example, TAM model was used by Al-Ghahtani (2008) in the context of Saudi Arabia by examining the technology acceptance in workplaces. It was created to enable the researcher to apply the model in a secondary school teachers' context in Saudi Arabia. From the modified version of the TAM the external variables were formulated to be applied in a Saudi Arabian context.

As the diagram shows below (Figure 1) the ELTAM consists of ten independent variables (gender, age, educational level, specialization, teaching experience teachers' ICT skills, students ICT skills, teachers' in-service training, ICT infrastructure and institutional policy leadership). There are also two intermediate variables: perceived usefulness (PU) and perceived ease of use (PEOU). In addition, there are three dependent variables adopted from TAM, which are teachers' attitude toward the use elearning, teachers' behavioural intention to use e-learning and teachers' actual use of e-learning. The ELTAM model used in this research includes Davis et al.'s (1989) original TAM model and additional external variables, mentioned above. 


\section{JRCIET}

Vol. 5, No. 2

April 2019

External Variables

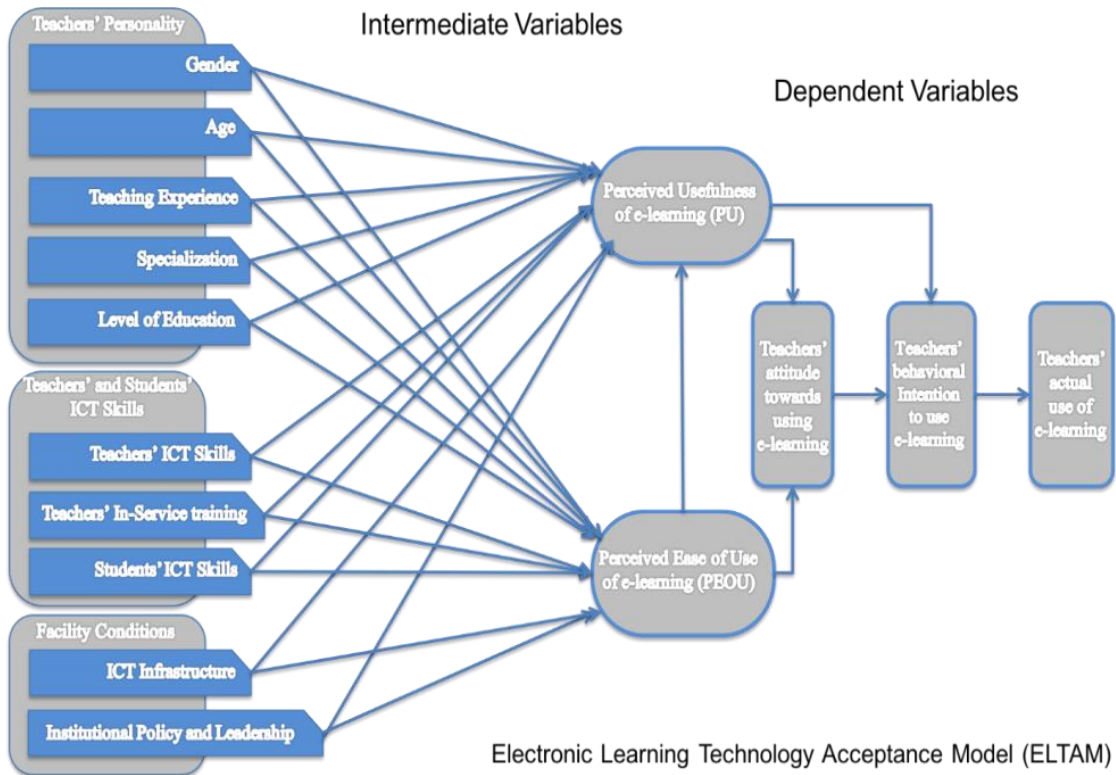

\section{Figure 1 ELTAM Research model}

\section{The role of the teacher in e-learning:}

There is much to be said for the teacher support in elearning. Daniel (2009: 2) defines e-learning as "the delivery of a learning, training or education programme by electronic means, involving the use of a computer or electronic device". However, it is not self-learning in isolation, but it is learning facilitated by technology (Emmett, 2001).

This clearly shows that Nichols (2003) is putting pedagogical considerations ahead of the technology supporting e-learning. The philosophy of e-learning must be seen ultimately as learning being delivered by means of accessible technology. The context of Saudi Arabia, e-learning is in its infancy with limited infrastructure and poor implementation, and there is a perception that the problem lies in the lack of infrastructure (Albugami and Ahmed, 2015). Strategic development of elearning should be based on the needs and demands of the learners and the quality of their educational experience (JISC, 2004: 9) 
The JISC (2004) report even suggests that the e-learning should stand for enhanced learning, rather than electronic learning; the criteria for effective practice in e-learning are the same as for any other mode of learning as pedagogy is the predominant factor. This means that e-learning should get the students involved in the activity of learning. Furthermore, elearning should result in autonomous learning. Moreover, elearning should contribute to what the students learn and how they improve what they can do. Finally, e-learning should result in a willingness to continue learning. The pedagogical approach may differ according to the experience of the teacher and the environment in which the learning takes place, but it should always be at the forefront.

\section{Methodology: Research method and instruments:}

Both paper-based and online questionnaires were distributed for data collection purposes. Approximately 1200 paper questionnaires were delivered to 38 secondary schools in Mecca in Saudi Arabia, the target population for this research. The subjects of the research were male and female full-time teachers of all subjects. The purpose of the questionnaire was to measure the factors influencing secondary school teachers' acceptance of e-learning in teaching. The researcher also used an online questionnaire, which was uploaded on to Survey Monkey and the link was sent to several head teachers using WhatsApp for them to distribute among their staffs. The WhatsApp program is used extensively in Saudi Arabia for group communications and is available in every school. According to Bryman (2004), structured interviews and questionnaires are commonly used effectively. A questionnaire is normally a structured set of questions whose aim is to gather sufficient data about the population (Payne \& Payne, 2004).

\section{Respondents:}

The target respondents of this research were secondary school teachers both male and female from Mecca region in Saudi Arabia. In total, there are 249 secondary schools in Mecca consisting of 128 boys' secondary schools and 121 girls' 
secondary schools. There are 7084 secondary school teachers in Mecca, 3379 male teachers and 3705 female teachers. Secondary schools were selected because the pupils are being prepared for university entrance, and between the ages 15-18 years they are able to deal with ICT. 1,200 questionnaires were distributed to secondary school teachers in the selected schools, in the second semester 2014. 669 (56\%) questionnaires were collected and 509 were used for the analysis. 160 questionnaires were returned but were not used because they were incomplete; they had up to $80 \%$ missing data. Online questionnaires also were distributed to some secondary school teachers, 52 online questionnaires were received and 27 questionnaires were completed and so could be used in the analysis, The questionnaires were distributed from the end of April until the end of May 2014 during the second semester at a time when the all teachers and students were attending school.

\section{Questionnaire structure and measurement:}

The questionnaire was divided into three sections. The first section considered the demographic characteristics of the respondents. The questions in this section were designed to elicit details of the teachers' background including gender, age group, level of education, specialisation and teaching experience. The second section is designed to gather data relevant to the technology acceptance model (TAM), its constructs and external variables, which include (gender, age, level of education, specialization, teaching experience, ICT teachers' skills, ICT students' skills, In-serves training). The inclusion of these items has been validated by their use in previous studies as described earlier. The third section is concerned with ICT infrastructure and technical support within schools, which includes ICT infrastructure and institutional policy and leadership.

The survey split the measurement of the constructs into sixteen questions covering 75 items. The first part covered demographic characteristics (age, gender, level of education, specialisation and teaching experience). The second part relate to the construction of the TAM model and all the necessary 
external variables (Teachers personality, teachers and student's ICT skills and facilities condition). The choice of the different items was based on previous studies in the field of technology acceptance models.

\section{TAM constructs:}

In this research, the technology acceptance model (TAM) was used as a base model to investigate and measure Saudi Arabian secondary School teachers' acceptance of e-learning technology in teaching and learning. Lee et al, (2003) state that the majority of research using the technology acceptance model processed quantitative data gathered from questionnaire based field studies, for example, (Al-Gahtani, 2008; Al-Saif, 2007; Brown et al, 2003; Straub et al, 1997; Venkatesh \& Morris, 2000; Venkatesh \& Davis, 2000).

\section{Research hypotheses:}

The main objective of this research is to examine secondary school teachers' acceptance of e-learning technology in teaching by empirically testing the theoretical ELTAM model shown in table 1 below and in figure 2, and the relationships between the differing elements of the model. This research includes 26 hypotheses, which, will be tested in a quantitative way, through the analysis of data gathered from school teachers relevant to this research. The number of hypotheses in this research is approximately the same in previous similar research, such as by Swesi (2011), who has used 23 hypotheses and Kripanont (2007), who has used 22 hypotheses. The research was developed according to the ELTAM model (Figure 1) which is based on the TAM. The research hypotheses were developed from the research model, research factors and research question and with reference to the existing TAM research findings.The table below (1) shows the relationships between the research variables and research hypotheses that have guided this research.

\section{Analysis: Statistical tests used in the research:}

The SPSS 21.0 and SmartPLS 2.0 computer programmes were used to analyse the data from the questionnaires. This 
research uses an array of different statistical techniques. Descriptive statistics, Chi-square tests, t-tests, ANOVA and correlations were carried out using SPSS 21.0. SmartPLS 2.0 was used to carry out PLS path modeling.

\section{Table (1) The relationships of research factors and research hypotheses}

\begin{tabular}{|c|c|c|c|}
\hline $\begin{array}{c}\text { Research } \\
\text { Factors }\end{array}$ & Hypotheses & $\begin{array}{c}\text { Research } \\
\text { Factors }\end{array}$ & Hypotheses \\
\hline Gender & $\begin{array}{l}\text { H 1. The gender of the teacher } \\
\text { will have a significant impact } \\
\text { on perceived usefulness (PU) } \\
\text { of e-learning technology } \\
\text { among secondary school } \\
\text { teachers. } \\
\text { H 12. The gender of the } \\
\text { teacher will have has a } \\
\text { significant impact on } \\
\text { perceived Ease of Use (PEOU) } \\
\text { of e-learning among secondary } \\
\text { school teacher. }\end{array}$ & $\begin{array}{l}\text { Students' } \\
\text { ICT skills }\end{array}$ & $\begin{array}{l}\text { H 8. Students' ICT skill will } \\
\text { have a positive impact on } \\
\text { perceived usefulness (PU) of e- } \\
\text { learning among secondary } \\
\text { school teachers in Saudi Arabia. } \\
\text { H 19. Students' ICT skill will } \\
\text { have a positive impact on } \\
\text { perceived Ease of Use (PEOU) } \\
\text { among secondary school } \\
\text { teachers in Saudi Arabia. }\end{array}$ \\
\hline Age & $\begin{array}{l}\text { H 2. The Age of the teachers } \\
\text { will have a negative impact on } \\
\text { perceived usefulness (PU) of e- } \\
\text { learning technology among } \\
\text { secondary school teachers. } \\
\text { H 13. The Age of the teacher } \\
\text { will have a negative impact on } \\
\text { perceived Ease of Use (PEOU) } \\
\text { of e-learning among secondary } \\
\text { school teacher. }\end{array}$ & $\begin{array}{l}\text { ICT } \\
\text { Infrastruct } \\
\text { ure }\end{array}$ & $\begin{array}{l}\text { H 9. ICT infrastructure will } \\
\text { have a positive impact on } \\
\text { perceived usefulness (PU) of e- } \\
\text { learning among secondary } \\
\text { school teachers in Saudi Arabia. } \\
\text { H 20. ICT infrastructure will } \\
\text { have a positive effect on } \\
\text { perceived Ease of Use (PEOU) } \\
\text { among secondary school } \\
\text { teachers in Saudi Arabia. }\end{array}$ \\
\hline $\begin{array}{l}\text { Teaching } \\
\text { experience }\end{array}$ & $\begin{array}{l}\text { H 3. Teachers' teaching } \\
\text { experience will have a positive } \\
\text { impact on perceived } \\
\text { usefulness (PU) to use e- } \\
\text { learning technology among } \\
\text { secondary school teachers in } \\
\text { Saudi Arabia. } \\
\text { H 14. Teachers' teaching } \\
\text { experience has a statistically } \\
\text { significant impact on } \\
\text { perceived Ease of Use (PEOU) } \\
\text { e-learning technology among } \\
\text { secondary school teachers in } \\
\text { Saudi Arabia. }\end{array}$ & $\begin{array}{l}\text { Institution } \\
\text { al Policy } \\
\text { and } \\
\text { Leadership }\end{array}$ & $\begin{array}{l}\text { H 10. Institution policy and } \\
\text { leadership will have a positive } \\
\text { impact on perceived usefulness } \\
\text { (PU) of e-learning among } \\
\text { secondary school teachers in } \\
\text { Saudi Arabia. } \\
\text { H 21. ICT infrastructure will } \\
\text { have a positive impact on } \\
\text { perceived Ease of Use (PEOU) } \\
\text { among secondary school } \\
\text { teachers. }\end{array}$ \\
\hline $\begin{array}{l}\text { Specializatio } \\
\text { n }\end{array}$ & $\begin{array}{l}\text { H 4. Teachers' specialization } \\
\text { will have a positive impact on } \\
\text { perceived usefulness (PU) of e- } \\
\text { learning among secondary } \\
\text { school teachers in Saudi } \\
\text { Arabia. } \\
\text { H 15. Teachers' specialization } \\
\text { will have a positive impact on } \\
\text { perceived Ease of Use (PEOU) } \\
\text { among secondary school } \\
\text { teachers in Saudi Arabia. }\end{array}$ & $\begin{array}{l}\text { Perceived } \\
\text { Ease of use } \\
\text { (PEOU) }\end{array}$ & $\begin{array}{l}\text { H 11. Perceived Ease of Use } \\
\text { (PEOU) of e-learning } \\
\text { technology will have a positive } \\
\text { impact on Perceived Usefulness } \\
\text { (PU) of e-learning among } \\
\text { secondary school teachers' in } \\
\text { Saudi Arabia. } \\
\text { H 23. Perceived Ease of Use } \\
\text { (PEOU) of the E-learning } \\
\text { technology will have a positive } \\
\text { impact on attitude towards use } \\
\text { of E-learning among secondary } \\
\text { school teachers in Saudi Arabia. }\end{array}$ \\
\hline
\end{tabular}




\begin{tabular}{|c|c|c|c|}
\hline $\begin{array}{l}\text { Level of } \\
\text { education }\end{array}$ & $\begin{array}{l}\text { H 5. Teachers' educational } \\
\text { level will have a positive } \\
\text { impact on perceived } \\
\text { usefulness (PU) of e-learning } \\
\text { among secondary school } \\
\text { teachers in Saudi Arabia. } \\
\text { H 16. Teachers educational } \\
\text { level will have a positive } \\
\text { impact on perceived Ease of } \\
\text { Use (PEOU) among secondary } \\
\text { school teachers in Saudi } \\
\text { Arabia. }\end{array}$ & $\begin{array}{l}\text { Perceived } \\
\text { Usefulness } \\
\text { (PU) }\end{array}$ & $\begin{array}{l}\text { H 22. Perceived Usefulness } \\
\text { (PU) of e-learning technology } \\
\text { will have a positive impact on } \\
\text { teacher attitude towards use of } \\
\text { e-learning technology in Saudi } \\
\text { Arabia. } \\
\text { H 24. Perceived Usefulness } \\
\text { (PU) of e-learning will have a } \\
\text { positive impact on teachers } \\
\text { Behavioral Intention (BI) to use } \\
\text { the e-learning technology in } \\
\text { teaching. }\end{array}$ \\
\hline $\begin{array}{l}\text { Teachers' ICT } \\
\text { skills }\end{array}$ & $\begin{array}{l}\text { H 6. Teachers' ICT skills will } \\
\text { have a positive impact on } \\
\text { perceived usefulness (PU) of e- } \\
\text { learning among secondary } \\
\text { school teachers in Saudi } \\
\text { Arabia. } \\
\text { H 17. Teachers' ICT skills will } \\
\text { have a positive impact on } \\
\text { perceived Ease of Use (PEOU) } \\
\text { among secondary school } \\
\text { teachers in Saudi Arabia. }\end{array}$ & $\begin{array}{l}\text { Attitude } \\
\text { toward use } \\
\text { of e- } \\
\text { learning } \\
\text { (AT) }\end{array}$ & $\begin{array}{l}\text { H 25. Teachers' attitude } \\
\text { towards (TA) use of e-learning } \\
\text { will have a positive impact on } \\
\text { behavioral Intention (BI) to use } \\
\text { e-learning technology in } \\
\text { teaching. }\end{array}$ \\
\hline $\begin{array}{l}\text { Teachers' In- } \\
\text { Service } \\
\text { Training }\end{array}$ & $\begin{array}{l}\text { H 7. In- service training will } \\
\text { have a positive impact on } \\
\text { perceived usefulness (PU) of e- } \\
\text { learning among secondary } \\
\text { school teachers in Saudi } \\
\text { Arabia } \\
\text { H 18. In-service training will } \\
\text { have appositive impact on } \\
\text { perceived Ease of Use (PEOU) } \\
\text { among secondary school } \\
\text { teachers in Saudi Arabia. }\end{array}$ & $\begin{array}{l}\text { Behaviour } \\
\text { Intention } \\
\text { (BI) }\end{array}$ & $\begin{array}{l}\text { H 26. Teachers' behavioral } \\
\text { intention (BI) to use e-learning } \\
\text { technology will have a positive } \\
\text { impact on actual usage among } \\
\text { secondary school teachers in } \\
\text { Saudi Arabia. }\end{array}$ \\
\hline
\end{tabular}

\section{Results: Secondary school teachers' in-services training}

The analysis shows that the level of in-service training for teachers was perceived as insufficient. (table 2) shows that the above findings tend to indicate that only $60 \%$ of respondents attended in-service training of which $33 \%$ are male teachers and $27 \%$ are female teachers.

\section{Teachers' experience with ICT and www}

Teachers' experiences in dealing with information communication technology and the World Wide Web (WWW) are shown in Table 3 Respondents were asked to rate their experience / competence in using computers and the internet with respect to three categories, "beginners", "intermediate" and "advanced". Approximately $64.8 \%$ of teachers are at intermediate level, while only $7.7 \%$ are beginners, and about $27.5 \%$ are at the advanced level. 
Table 2 respondent attendance training courses, seminars, workshops \& conferences

\begin{tabular}{|c|c|c|c|c|c|c|c|}
\hline $\begin{array}{l}\text { Respondent } \\
\text { attendance } \\
\text { training. }\end{array}$ & Gender & $\begin{array}{c}\text { Not at } \\
\text { all }\end{array}$ & Once & Twice & $\begin{array}{l}\text { Three } \\
\text { times }\end{array}$ & $\begin{array}{l}\text { More } \\
\text { than } 4\end{array}$ & Total \\
\hline \multirow{3}{*}{$\begin{array}{l}\text { Courses in- } \\
\text { service } \\
\text { training } \\
\text { On } \\
\text { education } \\
\text { technology. }\end{array}$} & Male & $\begin{array}{r}109 \\
21 \%\end{array}$ & $\begin{array}{c}38 \\
7.5 \%\end{array}$ & $\begin{array}{c}46 \\
9.0 \%\end{array}$ & $\begin{array}{c}32 \\
6.3 \%\end{array}$ & $\begin{array}{c}41 \\
8.1 \%\end{array}$ & $\begin{array}{c}266 \\
52.3 \%\end{array}$ \\
\hline & Female & $\begin{array}{c}98 \\
19.3 \%\end{array}$ & $\begin{array}{c}56 \\
11.0 \%\end{array}$ & $\begin{array}{c}25 \\
4.9 \%\end{array}$ & $\begin{array}{c}25 \\
4.9 \%\end{array}$ & $\begin{array}{c}39 \\
7.7 \%\end{array}$ & $\begin{array}{c}243 \\
47.7 \% \\
\end{array}$ \\
\hline & Total & $\begin{array}{c}207 \\
40.7 \%\end{array}$ & $\begin{array}{c}94 \\
18.5 \%\end{array}$ & $\begin{array}{c}71 \\
13.9 \%\end{array}$ & $\begin{array}{c}57 \\
11.2 \%\end{array}$ & $\begin{array}{c}80 \\
15.7 \%\end{array}$ & $\begin{array}{c}509 \\
100.0 \%\end{array}$ \\
\hline \multirow{3}{*}{$\begin{array}{l}\text { Seminar on } \\
\text { education } \\
\text { technology. }\end{array}$} & Male & $\begin{array}{c}159 \\
31.2 \%\end{array}$ & $\begin{array}{c}74 \\
14.5 \%\end{array}$ & $\begin{array}{c}22 \\
4.9 \%\end{array}$ & $\begin{array}{c}12 \\
2.4 \%\end{array}$ & $\begin{array}{c}5 \\
1.0 \%\end{array}$ & $\begin{array}{c}266 \\
52.3 \%\end{array}$ \\
\hline & Female & $\begin{array}{c}145 \\
28.5 \%\end{array}$ & $\begin{array}{c}64 \\
12.6 \%\end{array}$ & $\begin{array}{c}17 \\
2.7 \%\end{array}$ & $\begin{array}{c}5 \\
1.0 \%\end{array}$ & $\begin{array}{c}6 \\
1.2 \%\end{array}$ & $\begin{array}{c}243 \\
47.7 \%\end{array}$ \\
\hline & Total & $\begin{array}{c}304 \\
59.7 \% \\
\end{array}$ & $\begin{array}{c}138 \\
27.1 \% \\
\end{array}$ & $\begin{array}{c}39 \\
7.7 \% \\
\end{array}$ & $\begin{array}{c}17 \\
3.3 \% \\
\end{array}$ & $\begin{array}{c}11 \\
2.2 \% \\
\end{array}$ & $\begin{array}{c}509 \\
100.0 \%\end{array}$ \\
\hline \multirow{3}{*}{$\begin{array}{l}\text { Workshop } \\
\text { on education } \\
\text { technology. }\end{array}$} & Male & $\begin{array}{c}149 \\
29.3 \%\end{array}$ & $\begin{array}{c}72 \\
14.1 \%\end{array}$ & $\begin{array}{c}31 \\
6.1 \%\end{array}$ & $\begin{array}{c}4 \\
0.8 \%\end{array}$ & $\begin{array}{c}8 \\
1.6 \%\end{array}$ & $\begin{array}{c}266 \\
52.3 \%\end{array}$ \\
\hline & Female & $\begin{array}{c}124 \\
24.4 \%\end{array}$ & $\begin{array}{c}76 \\
14.9 \% \\
\end{array}$ & $\begin{array}{c}29 \\
5.7 \% \\
\end{array}$ & $\begin{array}{c}6 \\
1.2 \% \\
\end{array}$ & $\begin{array}{c}8 \\
1.6 \% \\
\end{array}$ & $\begin{array}{c}243 \\
47.7 \% \\
\end{array}$ \\
\hline & Total & $\begin{array}{c}273 \\
53.6 \%\end{array}$ & $\begin{array}{c}148 \\
29.1 \%\end{array}$ & $\begin{array}{c}60 \\
11.8 \%\end{array}$ & $\begin{array}{c}12 \\
2 \%\end{array}$ & $\begin{array}{c}16 \\
3.1 \%\end{array}$ & $\begin{array}{c}509 \\
100.0 \%\end{array}$ \\
\hline \multirow{3}{*}{$\begin{array}{l}\text { Conference } \\
\text { on education } \\
\text { technology. }\end{array}$} & Male & $\begin{array}{c}226 \\
44.4 \%\end{array}$ & $\begin{array}{c}25 \\
4.9 \%\end{array}$ & $\begin{array}{c}13 \\
2.6 \%\end{array}$ & $\begin{array}{c}1 \\
0.2 \%\end{array}$ & $\begin{array}{c}1 \\
.2 \%\end{array}$ & $\begin{array}{c}266 \\
49.71 \%\end{array}$ \\
\hline & Female & $\begin{array}{c}205 \\
40.3 \%\end{array}$ & $\begin{array}{c}27 \\
5.3 \%\end{array}$ & $\begin{array}{c}9 \\
1.8 \%\end{array}$ & $\begin{array}{c}\mathbf{0} \\
\mathbf{0 \%}\end{array}$ & $\begin{array}{c}2 \\
0.4 \%\end{array}$ & $\begin{array}{c}243 \\
47.7 \%\end{array}$ \\
\hline & Total & $\begin{array}{c}431 \\
84.7 \%\end{array}$ & $\begin{array}{c}52 \\
10.2 \%\end{array}$ & $\begin{array}{c}22 \\
4.3 \%\end{array}$ & $\begin{array}{c}1 \\
0.2 \%\end{array}$ & $\begin{array}{c}3 \\
0.6 \%\end{array}$ & $\begin{array}{c}509 \\
100.0 \%\end{array}$ \\
\hline
\end{tabular}

Table 3 Respondent experience with ICT and the web

\begin{tabular}{|l|ccccc|}
\hline \multicolumn{5}{|c|}{ Teachers experience with ICT and WWW } \\
\hline \multirow{4}{*}{ Gender } & & Beginner & Intermediate & Advanced & Total \\
\cline { 2 - 6 } & & & & & \\
& Male & 25 & 183 & 58 & 266 \\
& & $4.9 \%$ & $36.0 \%$ & $11.4 \%$ & $52.3 \%$ \\
\cline { 2 - 6 } & Female & 14 & 147 & 82 & 243 \\
Total & & $2.8 \%$ & $28.9 \%$ & $16.3 \%$ & 47.7 \\
& & 39 & 330 & 140 & 509 \\
& & $7.7 \%$ & $64.8 \%$ & $27.5 \%$ & $100.0 \%$ \\
\hline
\end{tabular}




\section{ICT infrastructures in secondary schools in Saudi Arabia}

This section examines the level of infrastructures and technical support for the implementation and practice of elearning in secondary schools in Saudi Arabia. This infrastructure includes computer laboratories, educational resources centers, Internet access, projectors (data show), ICT technical support, school websites, interactive boards, iPad/ laptop availability, printers / scanners / digital cameras and software educational availability, see Tables below (5). The results showed that:

- Computer laboratory availability in both boys' and girls' secondary schools is good compared with other facilities.

- Educational resources center availability is considered either good or excellent in nearly $76 \%$ of respondents' schools.

- This research shows that 174 (34.2\%) teachers, of whom 48 (9.4\%) are male and $126(24.8 \%)$ are female, said that Internet access is not available.

- $100(19.6 \%)$ teachers reported that data projectors are not available in their schools, of whom 15 (2.9\%) are male teachers and 85 (16.7\%) are female teachers.

- Additionally, many respondents reported that the standards of technical support was bad, while the number reporting excellent ICT technical support is very low, at only 48 teachers, 33 (12.4\%) male and 15 (6.2\%) female.

- The statistics show that the male teachers are considerably more satisfied with the availability of this facility than female teachers.

- Large numbers of teachers surveyed (355 (69.7\%)) reported that iPads and laptops were not available in their schools.

- Educational software availability is also very low in secondary schools, especially in girls' schools. These results reflect the broad lack of educational software availability in secondary

\section{Hypothesis Testing using PLS Path Model}

PLS tests with bootstrapping procedures (Davison \& Hinkley, 2003) were carried out in order to provide confidence 
intervals for all parameter estimates, building the basis for statistical inference. Partial least squares (PLS) tests were carried out with the Smart PLS 2.0 program (Ringle et al., 2005).

\section{Teacher Personality and Perceived Usefulness of E- learning}

Hypotheses 1, 2, 3, 4, 5 about the effect Teacher Personality (gender, age, experience, specialization and education level on the Perceived Usefulness of e-learning. the coefficient is statistically insignificant $(\mathrm{p}>0.05)$. Thus, hypotheses are not supported; Therefore, teacher personality does not influence Perceived Usefulness of e-learning.

\section{Teacher and students' ICT skills and the Perceived Usefulness of E-learning}

The research has two hypotheses looking at the impact of teacher's ICT skills and the PU and one hypothesis related to the effect of students' ICT skills on PU.

The first hypothesis 6 is not supported as the coefficient is insignificant $(p>0.05)$. Therefore, teacher's skills do not influence perceived usefulness of e-learning.

The second hypothesis 7 is tested by two equations, and is partially supported, as the first equation is statistically insignificant ( $p>0.05)$, while the second equation is significantly $(p<0.05)$ related to Perceived Usefulness. Therefore, teacher's training moderately influences perceived usefulness of elearning.

Hypothesis 8 is not supported as the coefficient is statistically insignificant ( $p>0.05$ ). Therefore, students' ICT skills do not influence perceived usefulness of e-learning.

\section{Facilitating condition and Perceived Usefulness of E-learning}

Hypothesis 9 is not supported since the coefficient for ICT infrastructure is statistically insignificant $(p>0.05)$ so there is no relationship between facilitating condition and the Perceived Usefulness of e-learning. 
Hypothesis 10 is not supported since the coefficient is statistically insignificant $(p>0.05)$ so institutional leadership and policy do not influence perceived usefulness of e-learning.

Hypothesis 11 is supported since the coefficient is statistically insignificant $(\mathrm{p}>0.05)$ so Therefore, teacher's perceived ease of use influences perceived usefulness of elearning.

\section{Teacher Personality and Perceived Ease of Use of E- learning}

The relationships between different facets of teachers' personalities (gender, age, experience, subject specialization and educational level) and perceived use of e-learning were tested via five hypotheses $(12,13,14,15,16)$. All these hypotheses are not supported since the coefficient is statistically insignificant $(\mathrm{p}$ $>0.05$ ). Therefore, the research did not find any relationship between teachers' personalities and perceived ease of use of elearning.

\section{Teacher and Students' ICT skills Perceived Ease of Use of E-learning}

Hypothesis 17 is supported. The coefficient is significantly $(\mathrm{p}<0.01)$. Therefore, teacher skill influences Perceived Ease of Use.

Hypothesis 18 is not supported since the coefficient is statistically insignificant $(p>0.05)$. Therefore, the research did not find any relationship between teacher's training and perceived ease of use of e-learning.

Hypothesis 19 is not supported since the coefficient is statistically insignificant $(p>0.05)$. Therefore, the research did not find any relationship between students' ICT skills and Perceived Ease of Use of e-learning.

\section{Conclusion and future research :}

This research is amongst the first to study the use of elearning in secondary schools in Saudi Arabia. The research has demonstrated that, there needs to be further additional 
investigations in this area. Consequently, the researcher suggests that further studies are carried out as follows:

First, similar research investigations should be carried out in Saudi Arabia to provide further evidence on factors influencing secondary school teachers' acceptance of e-learning technology in teaching and to corroborate the present findings.

Second, another study should take place to ascertain the factors influencing secondary school students' acceptance of elearning technology in learning.

Third, additional research into the availability of the necessary ICT infrastructure throughout Saudi Arabian schools should take place in order to target under-resourced schools.

Fourth, an area that requires further investigation is the level of necessary skills to use e-learning for both teachers and students.

Fifth, as the researcher used exclusively quantitative methods in this research there is the opportunity to consider using amixed-methods involving both quantitative and qualitative methods in testing the technology acceptance model (TAM).

\section{Recommendations:}

Taking into account the literature review, and the research results, the researcher recommends the following:

- It is clear that the investment in in-service training for secondary school teachers is insufficient, as evidenced by the teachers' reports included in the present research. Therefore, the Ministry of Education should provide funds to finance training courses in the field of using new technology in teaching.

- An extensive programme of development is essential to successfully implement the required level of e-learning.

- Ministry of Education in Saudi Arabia should implement a compulsory system of continuing professional development for teachers. 
- Good Internet access should be provided for all teachers and students in Saudi Arabian school, including sufficient numbers of computers and other relevant technological equipment.

- immediate improvement is possible through additional training, but in the longer term a much higher provision of ICT equipment, designed for use in the educational context is essential.

\section{References:}

Ahmed, S, (2013) Reliance on mobile phones for various tasks up in Kingdom. NewsWala. Retrieved from http://www.newswala.com/International-News/Relianceon-mobile-phones-for-various-tasks-up-in-kingdom37257.html. Accessed on 23 / 3 / 2016.

Ageel, M, (2011) "The ICT Proficiencies of University Teachers in Saudi Arabia: A Case Study to Identify Challenges and Encouragements", Hummingbird, University of Southampton's Doctoral Research Journal, Vol. 8, No. 21, 55-60.

Al-bugarni, S., \& Ahmed, V, (2015) "Success factors for ICT implementation in Saudi secondary schools: From the perspective of ICT directors, head teachers, teachers and students", International Journal of Education and Development using Information and Communication Technology, Vol. 11, No. 1, 36-54.

Al-gahtani, S., (2008) "Testing for the Applicability of the TAM Model in the Arabic Context: Exploring an Extended TAM with Three Moderating Factors", Information Resources Management Journal, Vol. 21, No. 4, 1-26.

Al-harbi, S., \& Drew, S., (2014) “Using the technology acceptance model in understanding academics' behavioural intention to use learning management systems", International Journal of Advanced Computer Science and Applications, Vol. 5, No. 1, 143-155.

Al-malki, G. \& Williams, N, (2012) "A strategy to improve the usage of ICT in the kingdom of Saudi Arabia primary 
school", International Journal of Advanced Computer Science \& Application,Vol. 3, No. 10, 42-52.

Al-marwani, A, (2011) ML for EFL: Rationale for mobile learning. In Proceedings of the International Conference "ICT Language learning" 4th Edition. Retrieved from http://conference.pixel-

online.net/ICT4LL2011/common/download/Paper_pdf/IB L52-365-FP-Almarwani-ICT4LL2011.pdf. Accessed on 1 / 4/ 2016.

Al-Mulhim, E, (2014) "The barriers to the use of ICT in teaching in Saudi Arabia: A review of literature", Universal Journal of Educational Research, Vol. 2, No. 6, 487-493.

Al-Shehri, S., (2012) Contextual language learning: the educational potential of mobile technologies and social media. Unpublished PhD Thesis: The University of Queensland.

Bell, F., Keegan, H. \& Zaitseva, E. (2008) "Designing virtual student mobility". In E. O'Doherty (Ed.), Conference Proceedings: Education in a Changing Environment Vol. 4, Santa Rosa, CA: Informing Science Press, p. 59-67.

Bryman, A., (2004) "Qualitative research on leadership: a critical but appreciative review", The Leadership Quarterly, Vol. 15, No. 6, 729-769.

Chen, R. J., (2010) “Investigating models for pre-service teachers' use of technology to support student-centered learning", Computers \& Education, Vol. 55, No. 1, 32-42.

Daniel, J., (2009) E-learning for Development: Using Information and Communications Technologies to Bridge the Digital Divide, London: Commonwealth Ministers Reference Book, Henley Media Group.

Davis, F. D., (1989) "Perceived Usefulness, perceived ease of use, and user acceptance of information technology", MIS Quarterly, Vol. 13, No. 3, 319-340. 
Davison, A. C., \& Hinkley, D. V., (2003) Bootstrap methods and their application. New York, NY: Cambridge University Press.

De Smet, C., Bourgonjon, J., De Wever, B., Schellens, T., \& Valcke, M., (2012) "Researching instructional use and the technology acceptation of learning management systems by secondary school teachers", Computers \& Education, Vol. 58, No. 2, 688-696.

Emmett, S., (2001) "E-Learning: A Philosophy Not a Manifesto", Online Available at: http://globalscgroup.com/e-learninga-philosophy-not-a-manifesto Accessed 18/04/2014.

Gong, M., Xu, Y., \& Yu, Y. (2004) "An enhanced technology acceptance model for web-based learning", Journal of Information Systems Education, Vol. 15, No. 4, 365-374.

Islam, A. N., Azad, N., Mäntymäki, M., \& Islam, S. S., (2014) "TAM and E-learning Adoption: A Philosophical Scrutiny of TAM, Its Limitations, and Prescriptions for E-learning Adoption Research", In Li, H., Mäntimäki, M., \& Zhang, X. (Eds.), Digital Services and Information Intelligence, London: Springer, 164-175.

JISC (2004) Effective Practice with E-Learning: A Good Practice Guide in Designing for Learning, Bristol: JISC Development Group.

Kripanont, N., (2007) Examining a Technology Acceptance Model of Internet Usage by Academics within Thai Business Schools, unpublished Ph. D. thesis: Victoria University Melbourne, Australia.

Lee, Y., Kozar, K. A., \& Larsen, K., (2003) "The technology acceptance model: past, present, and future", Communication of the Association for Information Systems, Vol. 12, No. 50, 752-780.

Legris, P., Ingham, J., \& Collerette, P., (2003) "Why do people use information technology? A critical review of the technology acceptance model", Information \& Management, Vol. 40. No. $3,191-204$. 
Lobo, S., \& Elaluf-Calderwood, S, (2012) "The BlackBerry veil: mobile use and privacy practices by young female Saudis", Journal of Islamic Marketing,Vol. 3, No. 2, 190 - 206.

Mari, M, (2013).Twitter usage is booming in Saudi Arabia. Globalwebindex, Retrieved from http://blog. Global webindex. net/twitter-usage-is-booming-in-saudi-arabia/. Accessed on 9/4 / 2016

Mohamed, A.H., Abuzaid, R.A., \& Benladen, R.M. (2008) "Opportunities and challenges of the knowledge management approach to e-learning: a case study in AlBayan Girls' School, Kingdom of Saudi Arabia", The Electronic Journal of Information Systems in Developing Countries, Vol. 35, No, 4, 1-11.

Ngai, E.W. T., Poon, J. K. L., \& Chan, Y. H. C., (2007) Empirical examination of the adoption of WebCT using TAM, Computers \& Education, Vol. 48, No. 2, 250-267.

Nichols, M., (2003) "A Theory for eLearning”, Educational Technology \& Society, Vol. 6, No. 2, 1-10.

Oyaid, A., (2009) Education Policy in Saudi Arabia and its Relation to Secondary School Teachers' ICT Use, Perceptions, and Views of the Future of ICT in Education, PhD thesis: University of Exeter.

Payne, G., and Payne, J., (2004) Key Concepts in Social Research, London: Sage Publication.

Pelgrum, W. J., (2001) "Obstacles to the integration of ICT in education: Results from a world-wide educational assessment", Computers and Education, Vol. 37, No. 2, 163178.

Ringle, C. M., Wende, S., \& Becker, J-M., (2005) SmartPLS Version 2.0 (beta), Hamburg: University of Hamburg.

Schoepp, K., (2005) "Barriers to technology integration in a technology-rich environment", Learning and Teaching in Higher Education: Gulf Perspectives, Vol. 2, No. 1, 1-24.

Shee, D. Y., \& Wang, Y. S., (2008) "Multi-criteria evaluation of the web-based 
e-learning system: A methodology based on learner satisfaction and its applications", Computers \& Education, Vol. 50, No. 3, 894-905.

Šumak, B., Heričko, M., \& Pušnik, M., (2011) "A meta-analysis of e-learning technology acceptance: The role of user types and e-learning technology types", Computers in Human Behavior, Vol. 27, No. 6, 2067-2077.

Swesi, K., (2011) An Investigation into the Influence of Learning Styles and other Factors Affecting Students' Perception of Virtual Learning Environments, PhD thesis: University of De Montfort University. 